\title{
Iran's Eastern Policy: Potential and Challenges
}

Mehdi Sanaei, Jahangir Karami

\author{
Mehdi Sanaei, PhD in Political Science \\ University of Tehran, Iran \\ Associate Professor \\ Academic IDs: UT26610 \\ Tel.: +982188630931 \\ E-mail: msanaei@ut.ac.ir \\ Address: University of Tehran, Enghelab Str., Tehran 14395-515, Iran \\ Jahangir Karami, PhD in International Relations \\ University of Tehran, Iran \\ Associate Professor \\ Academic IDs: UT26974 \\ Tel.: +982188630932 \\ E-mail:jkarami@ut.ac.ir \\ Address: University of Tehran, Enghelab Str., Tehran 14395-515, Iran \\ DOI: $10.31278 / 1810-6374-2021-19-3-25-49$
}

\begin{abstract}
In recent years, Iranian senior officials have laid stress on the Eastern course in foreign policy. This orientation has been discussed by various analysts and raised diverse perspectives. The present paper sets to explore Iran's Eastern policy in terms of its opportunities and limitations. It raises the important question of what the main features of Iran's Eastern strategy are and what potential and constraints it has. The authors assume that Iran's Eastern policy is both a reaction to the Western pressure and a proactive move in the currently changing global environment which contains both challenges and opportunities for its bilateral, regional, and international interactions. Although it can be useful for Iran's activism
\end{abstract}


at the bilateral and regional levels, a macro-strategy is required at the international level where the pivot to the East is a vital component. To explore the conception, the basis, goals, and dimensions of Iran's Eastern policy are laid down and the possibilities and instruments for its implementation are explored. The article concludes with the discussion of the constraints and challenges of Iran's Eastern policy and the implications it may have in the future.

Keywords: Iran, Russia, China, India, Eastern policy, foreign policy, Asia.

ince the 1979 Revolution, the foreign policy of the Islamic Republic of Iran has relied on the "Neither East nor West" motto. It was based on the Constitution of the Islamic Republic drafted amid the Cold War in the bipolar system and under the independent approach assumed by Iran's newly established government. The end of the Cold War, the increasingly strained relations with the West and the intense regional rivalries pushed Iran farther from the West and closer to Russia and China. This was especially the case under President Mahmoud Ahmadinejad (2005-2013), when both he and his foreign minister stressed the need for an "Eastern policy" in Iran's international affairs, which was later reinforced by the adoption of six UN Security Council resolutions on Iran's nuclear program. This shows that Iran's Eastern policy was not given serious attention abroad. However, after Hassan Rouhani took office in 2013, which paved the way for the JCPOA agreement and, accordingly, for "constructive engagement" with the world, a kind of balance reigned in Iran's foreign policy. However, U.S. President Donald Trump's withdrawal from the Iran Nuclear Deal once again raised the issue of the "Eastern policy" and this time it seems that even moderate and reformist politicians, frustrated with Iran's engagement with Western governments, emphasize its importance.

In view of Iran's parliamentary election results in early 2020 and the forecasts made about the upcoming presidential election slated for 2021, it seems that the "pivot to the East" will dominate the macro- 
trends in Iran's foreign policy in the coming years. Thus, this article attempts to shed light on major points of Iran's Eastern policy. To this end, the following questions have been formulated as primary queries: 1)What are the characteristics, possibilities, and constraints of Iran's Eastern strategy? 2)Will this strategy be able to essentially meet the fundamental needs of Iran's national security and interests?

This paper addresses the following conception: Iran's Eastern strategy is both a reaction to Western pressure and an action in the changing global political environment and contains both potential challenges and opportunities for bilateral, regional, and international relations. Iran needs a macro-strategy at the international level with the pivot to the East as its vital component. To explore this conception, the basis, goals and dimensions of Iran's Eastern policy are laid down and the possibilities and instruments for its implementation are analyzed. In conclusion, the article discusses the constraints and challenges of the Eastern policy and its implications for the future.

\section{THE FUNDAMENTALS OF THE EASTERN POLICY}

Iran's Eastern policy is rooted in a set of factors inside and outside Iran, especially those that emerged after the end of the Cold War in 1991. Below we will explain their various dimensions and how they affect Iran's foreign policy.

Since the 1979 Islamic Revolution, Iran's relations with the West have consistently been strained. The rupture of diplomatic relations with the U.S., coupled with the problems and disputes in Iran's bilateral relations with the West, landed Iran and Western countries into a tense, uncertain territory despite the conclusion of Sadabad Agreement in 2003 followed by the JCPOA in 2015. This prompted Iran to adopt a special foreign policy strategy to take the edge off the Western pressure; it has come to be known as the "pivot to the East," or "Eastern strategy."

The Eastern strategy concept came to the fore in the 1990s to step up relations with Russia, China, India, and other Eastern states, and even Latin America, particularly in the wake of the U.S. "Dual Containment" strategy in the Middle East. However, it primarily sought to curb relations with the U.S. and European countries and 
instead promote relations with Eastern powers. This was especially the case under President Mahmoud Ahmadinejad (2005-2013), when the head of state and his foreign minister stressed the need for this strategy, which practically enhanced Iran's relations with some Eastern countries, bringing China to the top position in the list of Iran's trade partners.

Although the "constructive engagement with the West" attitude had dominated Iran's foreign policy during the early presidency of Hassan Rouhani, Donald Trump's and his administration's growing hostility towards Iran, particularly after withdrawal from the JCPOA on May 8, 2018, once again foregrounded the Eastern policy. The hostility has made anti-Americanism in Iran's foreign policy more comprehensible. On that account, Moscow, Beijing, and New Delhi appear more flexible in balancing out their economic interests between the U.S. and Iran.

The key relevant idea has been the emphasis put by Iran's Supreme Leader Ayatollah Khamenei on the Eastern strategy. He underscored the concept on several occasions, saying: "One of our priorities today in foreign policy is preferring the East to the West, neighbors to remote countries and nations, and countries that share characteristics with us to others" (Khamenei, 2016a). Stressing "the necessity of establishing scientific communication with countries on a leaping trajectory," he stated that "these countries are primarily in Asia. We thus should look to the East than the West. In addition, looking to the West and Europe yields nothing than being kept waiting, currying favor with them and belittling oneself” (Khamenei, 2016b).

Ayatollah Khamenei's dedicated website gives six reasons for shifting Iran's preference to the East: access to bigger markets, proper trade balance, more shared interests, weaker influence of adversaries on the Eastern camp, advanced Eastern technological potential, and a variety of foreign currencies (Khamenei, 2018). The Eastern strategy thus has obvious economic and political justifications and clear goals which will be covered in the following sections.

In view of the absence of any prospects for a new deal and the volatility of past agreements, it seems that a major pursuit of these policies is neutralizing Western pressure while maintaining the 
government's autonomy to be able to serve the two-fold goal of reducing the pressures and ensuring the state's survival in the face of Western threats. These pressures have been in place in political, security and economic fields and have been mounting on a variety of pretexts. Iran interprets these pressures as the price of autonomy, while the U.S. and its allies attribute them to Iran's regional behavior.

In addition to rolling back Western pressure, Iran seeks, as part of its Eastern strategy, to capitalize on the transition of the international order to accelerate the process of the "West to East pivotal shift" and secure a niche in this new architecture. Thanks to its geopolitical position and its communication and economic infrastructure, Iran could play an important role in the new environment. Therefore, Iran's Eastern strategy is not a passive reaction; rather, it is a proactive move with long-term structural and functional goals at its heart at the national, regional, and global levels.

Iran also seeks to enter a coalition, which may well emerge. For Iranian statespersons, it is just a matter of time before the Russian and Chinese hostilities and rivalries with the Western bloc erupt into tension and conflict, and thus the inception of a rival coalition opposing the West is inevitable, and Iran wants a share in it (Velayati, 2018). One may say it is just a view in Iran, but this one is important as its proponents happen to be at the core of Iran's power and politics and make strategic calls in its foreign policy.

Although ideologically informed and pursuing clear-cut political goals to counter Western pressure, Iran's Eastern policy contains, in practice, an assortment of elements in geo-economic, geo-strategic, security, and international spheres. By nature, therefore, the Eastern strategy should be seen as a multi-faceted, multi-modal policy, each field of which is dealing with its own issues.

Geo-economic factors in Iran's Eastern policy outrun other elements in importance. In Iranian statespersons' view, international economic trends are shifting from the West to the East and East Asia, with China as its heart to be the driving force of global economic development and transformation in the near future (Abyaneh, 2021). In contrast to the previous decades, Western countries have been replaced 
as major trading partners with Eastern ones led by China and India. Numerous steps have also been taken to cultivate economic relations with Russia. In 2012, with the beginning of the new term of Vladimir Putin's presidency in Russia and the subsequent election of Hassan Rouhani in Iran, bilateral relations between Iran and Russia entered a new round, kick-starting important economic engagements. Iran's cooperation with Russia and India within the framework of the NorthSouth Transport Corridor and contribution to China's One Belt One Road Initiative are important steps in realizing the Eastern strategy.

Geopolitically, Iran is located in a complex regional environment. As the main force in the Persian Gulf region and a credible power in the Middle East, Iran connects these points to South Asia, Central Asia, and the Caucasus. This complex regional location has brought Iran close to India, China, and Russia. While India is the primary power in South Asia, China has secured a key position in Central Asia and plays an important role in the region as well as South Asia through the Shanghai Cooperation Organization (SCO) and the One Belt One Road Initiative in addition to being the primary trade partner of the region. As the Eurasian hegemonic power, Russia has forged important cooperation with Iran in the Caucuses and Central Asia and agrees on important points with Iran in Afghanistan and the Middle East. The concept of hegemonic power at the international or regional level refers to a country that is relatively higher than other powers economically, militarily, politically, institutionally, and normatively (see Dirzauskaite and Ilinca, 2017). This has made Iran an important pillar of Russia's Middle East policy where both governments share interests in preserving regional stability, from Afghanistan to Central Asia, the Caspian Sea region, the Caucuses, and the Middle East and have initiated cooperation in important areas. In his article Iran's Asianization, Ehteshami has put more emphasis on the geopolitical factor in the inception of the current Eastern strategy (Ehteshami, 2019, p. 11).

In geostrategic terms, the policies of regional and international rivalries have prompted the four great regions of the world-Europe, transatlantic with the U.S. as its center, Eurasia on the Russian axis, and 
East Asia with China as the pivot-to attach the greatest importance to shaping the international order architecture. There is no pivotal power in the Middle East while the rivalry among Iran, Turkey, and Saudi Arabia has created an unstable regional equilibrium which has consequently diminished the region's strategic standing in the course of global developments. These three powers' scramble to win the attention of global powers has given rise to a rivalry. Iran, on its own part, has attempted to enter into a wider geostrategic contest to play its regional and international role. Iran's relations with Russia and China will be crucial for redefining its global geostrategic status (Sanaei and Karami, 2019, pp. 22-24). Over time, these mutual threats have grown in complexity and extent to the point of proxy warfare and an increasing possibility of direct confrontation.

In security terms, Iran has faced consistent threats from the U.S., Israel, and Saudi Arabia in its post-Revolution security environment. Since the Iraq-Iran war (1980-1987), U.S. armed conflicts in 1990, 2001 and 2003 with Iraq, the Taliban, and subsequent occupation of Afghanistan and Iraq followed by the Arab Spring from 2011 onwards, Iran has stepped up its regional involvement to deescalate its security threats. The competing environment coupled with security puzzles has incited greater threats from both sides. To deescalate threats by the U.S. and its regional allies, as well as the terrorist threats from radical outfits such as ISIS and the Taliban, Tehran has entered into cooperation with Moscow.

Containing the pressure from international institutions is another dimension of Iran's Eastern strategy. In the past three decades, the U.S. has always been trying to use its global hegemonic instruments, such as international arms control processes, legal human rights regimes and other international mechanisms, in order to curtail and keep its rivals and adversaries in check. As a case in point, Iran has invariably been subject to international resolutions, particularly by the UN Security Council. Here, powers like Russia and China play an important role. However, this role is primarily driven by their relations with the U.S., on the one hand, and with Iran, on the other. As a matter of fact, important resolutions were adopted against Iran in 2008-2011 when 
the Russian-U.S. relationship had improved within the framework of the U.S. "Reset" initiative. However, relations between Tehran and Moscow have been on the rise since 2012 and up to date. The positive roles played by Russia and China in both the conclusion of the JCPOA and its post-U.S. withdrawal salvage have reduced the odds of pressuring Iran via international institutions (see Mahmoudian and Cafiero, 2021).

One can conclude from these important dimensions of Iran's Eastern policy that this is a strategy of different orders. The main pillars of the strategy are expanding economic and trade relations, countering extremism and terrorism, and ultimately, sculpting a coalition against the West. Moreover, this is a multi-faceted, multi-dimensional strategy and thus not easily alterable given its ideological nature, prospective fundamental importance, the regional environment, and the real conditions determining the engagement between Iran, the United States, and its allies. The security game between the West and Iran is evolving towards complexity, pressure and restrictions, making Iran's Eastern strategy the only viable option in the future.

\section{PRACTICAL POSSIBILITIES OF THE EASTERN POLICY}

Given the nature, goals and dimensions of Iran's Eastern strategy, as discussed in the previous section, one may now see what possibilities, instruments and opportunities Iran has at its disposal to realize the strategy and whether it will be feasible. The main proponents of the strategy believe that the Islamic Republic of Iran possesses important tools and capabilities to implement its Eastern strategy. In their view, Iran, with a population of about 80 million, a gross national product of about $\$ 400$ billion, an important military power in the region and a special geographical location at the center of international interactions has vast potential. Moreover, Iran has the world's second-largest natural gas reserves and the fourth-largest oil reserves, which gives it a significant weight in the Eurasian powers' strategic calculations underlying their foreign policies towards the Middle East (Musavian, 2020).

Many international observers believe that none of the regional problems can be resolved without Tehran's participation. Iran is an 
anchor of regional stability and security. Since the start of the Arab Spring in 2011, numerous countries in the Middle East have been grappling with instability and insecurity. In contrast, not only did Iran manage to withstand waves of instability, but it also proceeded to contribute to security and stability in Iraq, Syria, and Lebanon. This has been manifested in Iran's sustained and effective stabilizing role in Afghanistan with Russia's cooperation since the rise of the Taliban in 1996, and then after its fall. One should also note Iran's role in the security crises in the South Caucasus since 1991 and Tajikistan since 1992, which have been largely mediation-oriented and aimed at reconciliation and peace.

In the struggle against terrorism and insecurity in the region, in addition to the Iranian-Russian joint efforts against the Taliban, Iran's effective and fundamental cooperation with Russia and other countries against ISIS deserves attention as well. No one can forget the role played by Iran and its military commander, Lt. Gen. Qasem Soleimani in vanquishing ISIS in Iraq. Both the Iraqi central government and Iraqi Kurdistan were on the verge of imminent fall, and it was only with Iran's help that they managed to keep ISIS at bay (Gelali, 2019, Esmaeili, 2014).

Iran's institutional possibilities for implementing the Eastern policy should be noted as well. Since 2005, Iran has been an observer state in the SCO and has applied frequently for a full membership. If approved, the SCO membership could greatly contribute to the security and economic efficiency of this organization (Karami, 2015, p. 293). Besides, Iran's central role in the Economic Cooperation Organization (ECO) proves to be an important economic tool in strengthening the Eastern strategy. Economically speaking, the ECO is an important entity with potential for more active engagement (see Sanaei and Karami, 2018). In addition to Iran as one of its founding members, the Organization has Turkey, Pakistan, Afghanistan, Azerbaijan and five Central Asian countries on board.

Since the establishment of the ECO, transport and communications have been one of the priority areas of cooperation within the organization and their importance has been growing on a daily basis. 
The ECO's agenda includes implementing projects and programs to physically connect member countries and give them access to markets outside the region through existing transportation infrastructure. Linking the four regions of South Asia, the Persian Gulf, Central Asia, and the Caucasus is a feature of this organization.

The proposal of connecting the Indian subcontinent to Europe through the railway network of Pakistan, Iran, and Turkey has been discussed at various ECO meetings, and important steps have been taken in this regard. Therefore, cooperation between the ECO and the Eurasian Economic Union (EEU), as well as the SCO can be considered an important possibility for Eastern inter-regionalism.

Some analysts point to a number of other opportunities for Iran, the most important of which are: the possibility of cultivating close ties with powerful Eastern actors, relying on energy exports as a strategic commodity and Iran's trump card, particularly in relations with China and India and other Eastern countries; Iran's golden geopolitical and geoeconomic position in the region and by extension in the world; interdependence between countries and enhancing security in the new era (Adami, 2013, p. 120).

But how each of these goals and orders can be achieved is crucial. To implement its Eastern strategy, Iran places greater emphasis on relations with the Eastern world, particularly China, Russia, and India. Moscow, Tehran, and Beijing also share common strategic and longterm interests in rolling back U.S. unilateralism, which is one of the key factors in crafting the future of the Middle East. There is an important opportunity in this regard, because the Trump administration's policy of unilateralism and its withdrawal from international treaties (including the JCPOA) has called into question the legitimacy and credibility of the United States as a world power, while it is not clear if President Biden will manage to win back this credibility. Many countries around the world now see China as the future successor to the United States in global leadership (Pippa and Kristensen, 2018, p. 1). German Chancellor Angela Merkel, for instance, even in the midst of flailing Sino-European relations, said the EU had a "very strategic interest" in maintaining cooperation with China. 
"We Europeans must acknowledge China's determination to take the lead in existing international architectural structures," Merkel said. Given all these considerations, steps continue to be taken to coordinate Iran's, Russia's, and China's activities. One of the important examples of this cooperation should be seen in two military exercises that took place in 2019 and 2020 in the Sea of Oman and also in the North Caucasus, with the participation of the three countries.

Russia and China have rejected U.S. efforts to extend the UN arms embargo against Iran that expired in October 2020 under the terms of the 2015 Iran Nuclear Deal. Although it is unclear how much Russia and China will exercise efforts to strengthen Iran's militarily, Tehran remains the only option for Moscow and Beijing to balance arms sales in the region with the West. The United States is the largest supplier of weapons to 13 out of the 19 Middle Eastern countries, which amounts to about half of the region's weapon stocks. Europe supplies more than 20 percent of the region's weapons while Russia and China's arms deals account for about 20 percent. In short, U.S. coercive policies toward Iran, Russia, and China will continue to be a major obstacle to a tripartite strategic alliance (Esfandiary and Tabatabai, 2018). However, the fate of such a strategic agreement will be under the spotlight in the upcoming international relations (Musavian, 2020). One should also note Russia's and China's plans for security and cooperation in the Persian Gulf in the last two years, which, if put next to the joint military exercises held in the Sea of Oman in 2019, clearly indicate that the two countries' policies towards the region have altered.

Apart from multilateral interaction envisaged by Iran's Eastern strategy, bilateral relations between Iran and the main Eastern countries are also of great importance. Bilateral relations between Iran and China have historically been good and positive. In recent years, economic engagement between the two countries has been on the rise, and unlike relations with other major powers, the social basis of these relations has been less negative and inhibitive. China's growing power and role and escalating tensions with the United States have made China more important to all countries in the world. Moreover, China's current strategy for building a global network of partnerships, in line with the 
idea of a "harmonious world" and the new concept of "Community of Common Destiny" (Grachikov, 2020), is ever more important in the case of Iran.

Bilateral relations between Iran and China have expanded greatly in recent years, with China leapfrogging other countries to become Iran's number one trading partner. The two countries' trade turnover stood at about $\$ 10$ billion in 2010, peaking at about $\$ 22$ billion in 2014 and $\$ 37$ billion in 2017, and the 25-year Iran-China agreement has set the two countries on a path to long-term and strategic cooperation (See Keller, 2020). Statistics show that relations between Tehran and Beijing have been growing since 2000. They gathered even more pace during the period of international sanctions against Iran, with trade between the two countries reaching its peak between 2008 and 2016, when the sanctions were in full swing. The 25-year Iran-China Strategic Partnership Agreement has caused quite a stir in Iran's political and media circles over the past year. Proponents see it as an important achievement in the face of U.S. pressure, while opponents interpret it as selling the country to the Chinese. If concluded, it is not yet clear to what extent the agreement would be feasible.

Iran-China regional relations are yet to be activated and China does not yet have an effective regional policy in the Middle East. China, nevertheless, has important regional plans in Central and South Asia. In Central Asia, the One Road One Belt Initiative does not conflict with Iran's interests, and Iran has sought to play an effective role in interacting with the initiative. Iran's position on this route is so important that even Chinese President Xi Jinping has mentioned the country as a major transit route for the Silk Road-Iran is too important for Beijing to ignore. It should also be noted that agreements have been reached to extend the Middle East Corridor to South and East Asia, that is, from Turkey and Iran via Pakistan to India and then through Bangladesh to Southeast Asia (Irna, 2019).

Another Chinese plan is to build a communication corridor through South Asia and Pakistan, from inside Chinese territories to the Gwadar port near the Iranian border. Although this plan raised concerns in the Indian government, it is a non-security issue for Iran. With the 
participation of India, Iran has tried to launch a communication corridor from Central Asia to the Persian Gulf, the Sea of Oman, and the Indian Ocean through the Chabahar port. Along with the NorthSouth corridor in partnership with Russia and India, this will create an important opportunity for Iran and other countries of the region. Naturally, India's participation in the routes connecting Central Asia, the Caspian region, and the Caucasus to Iran will be a cause of concern for China. Iran is striving to prevent this issue from sparking rivalry between the two Asian powers. But if India really takes important practical steps to realize these corridors, Iran-China relations will naturally undergo changes (for more reading, see Richardson, 2020).

China is yet to be recognized as an influential actor in important international arenas. On issues such as Iran's nuclear program or unilateral U.S. sanctions, Beijing has been less active, opting instead to follow the Russian example.

Both China and Russia are concerned about the involvement of international institutions in their domestic affairs just like with the replacement of the international Westphalian order with a post-Westphalian incarnation, hence vetoing any such resolutions. Therefore, the Chinese, like the Russians, will support Iran as long as the Iranian nuclear issue is raised as part of the JCPOA and Iran acts within its framework.

Hence, China can be considered an important element of Iran's Eastern policy. However, the nature and extent of these relationships should not be exaggerated. Iran's domestic situation, and particularly its public opinions and media space limit Iran's relations with Eastern powers. On the other hand, China does not entertain any serious intention to get involved in the Middle East issues or seriously compete with the United States and its allies. Rather, it sees these countries in such a way that it does not wish to enter into a major coalition with Iran.

From 1991 to 2020, Tehran-Moscow bilateral relations have experienced many ups and downs, and the two governments are currently under the pressure of different sanctions imposed by the West and the United States. Although the trade volume between the two countries rose from $\$ 400$ million in 1991 to about $\$ 3$ billion 
between 2000 and 2007, it went down under the Western sanctions. However, bilateral trade showed another upward trend since 2014 to reach about $\$ 2$ billion in 2019. Besides, worth mentioning are some major economic projects, such as the construction of new thermal power plants, two new nuclear power plants, and the allocation of $\$ 5$ billion by Russia to fund these projects.

The two countries, whose defense cooperation had largely come to a standstill due to the sanctions, implemented the S300 agreement which was later followed by much more intense defense cooperation (Sanaei, 2020). It should also be noted that the start of technical and military cooperation between Tehran and Moscow after the expiration of the arms embargo in November 2020 can prove very important.

As regards regional issues, the two countries have engaged in a number of regions and countries in recent years. Cooperation between the two governments has taken the form of countering extremism and separatism, supporting sovereign governments, helping resolve regional problems and crises, and launching military operations against terrorism. Although Tehran and Moscow have their own views on different issues and in some cases have conflicting interests, they share specific interests in the context of regional stability and security and opposition to U.S. interventionism and counterterrorism. As a matter of fact, Tehran-Moscow relations have been more security-focused in nature, unlike relations with China which have been largely economic.

One of the highlights of Iran-Russia relations has been military cooperation in the fight against terrorism, which can be described as a strategic partnership. Even their disagreements on the Syria crisis did not stop them from launching significant military operations in support of the legitimate Syrian government, the country's territorial integrity, and the stability and security of the region in the face of terrorism. Therefore, the strategic partnership between Tehran and Moscow against terrorism was able to maintain, more or less, national and regional security in Syria and the eastern Mediterranean. But the two countries are yet to work out a clear solution for the postcrisis era which could have negative impacts on bilateral relations. In fact, without a concrete plan for future relations between the two 
countries, especially on regional issues, strategic partnership will shrink significantly.

Another important feature of Iran's economic cooperation with Russia is the former's proximity to the EEU's member states. Iran shares a land border with Armenia and a sea border with Russia and Kazakhstan. One of Iran's trade priorities in recent years has been cooperation with the EEU, and about three years ago the two sides began extensive negotiations on the establishment of a free trade area and have reached some results. Also, the cooperation agreement between Iran and the EEU is an important opportunity for both Iran and the EEU member countries.

Iran and the Eurasian Economic Union began negotiations on a preferential tariff in 2016 and reached an agreement in 2018. This agreement is an important achievement when it comes to cooperation between Iran and the EEU. The two sides have reached a three-year agreement on a free trade area, stipulating that during this period, the parties must accept the conditions for achieving a full free trade plan for tariff-free essential commodities.

Iran is a pivotal country in the International North-South Transport Corridor Agreement, signed in 2000 in St. Petersburg by the ministers of transport of Iran, India, and Russia. The corridor was established to promote transport cooperation between its members, connecting the Indian Ocean and the Persian Gulf to the Caspian Sea via Iran and then to northern Europe via Russia. The North-South Corridor is the most important trade link between Asia and Europe, which is very costeffective in terms of distance and time compared to traditional routes. The North-South Corridor is one of the most important transit routes in Central Asia, and the countries along this corridor develop and equip their ports, roads, terminals, and railways by setting up unions and concluding cooperation agreements in an all-out competition (Sarma, 2018).

Among most important international issues concerning the relations between the two countries Iran's nuclear file is of special importance. Russia joined the UN Security Council resolutions against Iran in 2006-2010, and this trend intensified mainly during 
the Medvedev-era Reset policy. However, since 2013, relations between the two countries have gradually been improving, with Russia playing an important role in the process of concluding and maintaining the JCPOA. We should also mention Russia's policy in the context of the Westphalian international system, which has been of great importance to Iran. Iran has welcomed Russia's anti-American stance that opposes NATO expansionism and other Western institutions in the Eurasian space, and this has created proper conditions for stronger relations between the two countries. In the field of international organizations, the Iran-Russia engagement had reached a point where Moscow for the first time used its veto right in favor of Iran to prevent the adoption of a resolution on February 2018 (Sanaei, 2020).

Despite significant regional experience gained in establishing stability and security in Tajikistan in the early 1990s and the second half of the same decade in Afghanistan in support of the Northern Alliance against the Taliban and then in recent years in Syria, Iran and Russia have not yet established clear mechanisms for crisis prevention and management and post-crisis reconstruction. It is thus necessary to institutionalize regional cooperation more than ever before and clearly define mechanisms and processes of interaction and consequences, as well as post-crisis conditions to prevent cooperation from degradation into short-lived, case-by-case and inhibitive ventures, and instead make it strategic, positive, and encouraging. This is especially important in the context of post-crisis cooperation in Syria.

Iran's Eastern policy has another pillar: India. The Iran-India relations have been positive and appropriate in all years of the former's independence, and a positive and favorable relationship between Iran and Pakistan has not had that much of a negative impact on them. Tehran and New Delhi have maintained low-tension bilateral relations in recent years, and close India-U.S. relations and India's being among U.S. allies in matters involving China have not yet compromised its relations with Tehran. Iran's hopes for India's participation in the North-South corridor project as well as the Central Asian corridor to the Sea of Oman and its investment in the Chabahar port development have not yet yielded practical results. India is wary of getting involved 
in acute international issues, and for this reason it is unlikely to enter into regional equations that Iran considers part of its Eastern policy. At the same time, the membership of India and Pakistan in the SCO shows the depth and complexity of the country's behavior on regional issues. While China and Pakistan are India's most important security and military concerns, its presence in such an institution is largely understood in terms of peacemaking and traditional nonalignment in foreign policy. In international affairs, too, India is merely playing a role in the Non-Aligned Movement, which has become an institution detached from current realities, and, therefore, India cannot be considered important for the international dimension of Iran's Eastern policy. As mentioned earlier, India attaches less importance to its relations with Iran because of its strategic relationship with the United States. But it seems that India's independent policy in international affairs, as well as the positive and appropriate experience of past relations with Iran make India an important partner for Iran in addressing non-political and non-security issues.

Summing up, among the three main Eastern countries, India is the least reliable one for Iran except for normal trade relations. In the case of China, however, it seems that the two countries can have important economic, trade and communication cooperation in light of the new strategic cooperation agreement. Nevertheless, the question of whether such cooperation could bring about a strategic security alliance should be considered more cautiously. In relations with Russia, despite the limited level of economic interaction, the combined technical and military efforts as well as cooperation in the fight against terrorism and support for regional stability and security will be very effective, and past experiences prove the effectiveness of the two countries' coalition against terrorist threats.

\section{CONSTRAINTS AND CHALLENGES OF THE EASTERN POLICY}

Iran's Eastern strategy, however, faces various constraints at home and abroad. There are several political forces vying for power in Iran, the most important of which are principlists, moderates, and reformists. The Eastern strategy is generally accepted by the principlists. In 
contrast, for the moderates, the Eastern strategy is pursued not as an anti-Western policy but as a way to defuse Western pressure. They do not consider the Eastern strategy to be strategic and long-term in nature but believe that there should be a balanced view of the country's foreign policy, and that maintaining balance in establishing foreign relations is crucial for Iran (Sajjadpour, 2018, p. 34). For the moderates, Iran's foreign policy should focus on its strategic environment and on global powers, and not divide the world into East and West.

The reformists, on the other hand, believe in a foreign policy that engages with Western governments. Although they regard relations with Eastern countries as important, the view held by a large number of reformists focuses mainly on engaging with the West and revising antiWestern concepts (see Hadian, 2018, p. 35). From the point of view of some others, the "policy of pivot to the East" could be constructive if it is pursued in the context of maintaining constructive and proportionate relations with the West. If Turkey manages to have extensive economic engagement with the West and then adds the Eastern option to our basket of choices, this can better serve its interests. However, pursuing the policy of "pivot to the East" triggered by frustration and urgency only serves the interests of countries such as Russia and China and leads to a pullback in pursuit of the country's interests due to Iran's current international position. The policy of "pivot to the East" is not wrong, but there must be a balanced approach to Iran's geopolitical requirements if it wishes to be close to Russia and China as well as the whole world (Koulaee, 2013).

Apart from the reformists, Iranian anti-government forces mainly emphasize hostility towards the Eastern regimes and an alliance with the West, and interpret any Eastern strategy solely in the interests of the Iranian government and not in the national interests. Some have attributed this strategy to the poor understanding of the international system, Iran's reactive foreign policy, the lack of initiative, and the absence of consensus on the assumptions, components and the very nature of this concept as well as to reliance on the doomed Third Force strategy. From this point of view, the strategy lacks fundamental values to ensure the national interests of the country (Arghavani, 2015, p. 30). 
An important constraint on the Eastern strategy is Iran's Constitution, as well as some ideological principles and the assumed independence of Iran's foreign policy. Naturally, any strategy of effective cooperation with great powers requires that independence of action be given up to some extent. This issue is subject to many restrictions under the Iranian Constitution. The Iranian Constitution, which was a by-product of the 1979 Iranian revolution, pre-revolutionary developments and the harsh experience of foreign interventions in Iran's domestic affairs since the 19th century by the great powers was drafted in such a manner as to emphasize the pessimism of any serious relations with major foreign powers. Iran's revolutionary ideology emphasizes "Neither East nor West" foreign policy, and this motto is still displayed on the website of the Iranian Ministry of Foreign Affairs as a constitutional principle. This approach has led the government to constantly emphasize its anti-American stance in justifying its relations with the East and responding to U.S. sanction pressure. Similarly, the government's opponents always emphasize the principles of revolutionary foreign policy against relations with the East.

And finally, we must mention more important constraints on the side of the Eastern powers. Iran's Eastern strategy has different levels and goals. At the level of economic cooperation, it seems that all three countries can be important for this strategy but relations with China have been particularly significant in recent years.

At the level of regional stability and counterterrorism, it is practically Russia that has come to the fore in the last three decades, and cooperation between the two governments in this regard has proved crucial. Although there are common interests with the governments of China and India, effective cooperation will not be on the cards until Iran's request for full membership in the SCO is accepted.

At the level of international cooperation, India does not hold much of importance. Russia and China take the lead in this respect, especially as Iran, China and Russia have common interests in maintaining the Westphalian system, upholding the principle of national sovereignty, non-interference by the West in the internal affairs of countries, and preventing international organizations, especially the United 
Nations, from abusing their power in a bid to pressure independent governments. So, as for the possibility of establishing an Eastern International Coalition, it should be emphasized that this probability is currently ruled out, and if such an option is possible between China and Russia, it certainly is not for Iran.

China needs to engage with Western powers in order to sustain its economic growth and development for decades to come. So, despite serious controversy with the United States on many issues, it is unwilling to get involved in security matters that go beyond its own vital national security interests in its immediate regional environment. As for Russia, although the Russian government has to deal with much more serious problems and security threats created by the West, it nevertheless seeks to interact with it and participate in the resolution of important strategic issues, such as cutting strategic weapons and maintaining global strategic stability in order to continue the competition with the West. Also, a strategic alliance or coalition would be feasible for Russia only within the framework of the Collective Security Treaty Organization.

Furthermore, Iran's Asian relations do not develop in a vacuum, and the Eastern states have close economic ties with other countries in the region, such as Saudi Arabia, the UAE, Qatar, and Kuwait, which are Iran's regional competitors and adversaries (Ehteshami and Bahgat, 2019, p. 32). So, if we look at the scale of China's, India's, and Russia's trade relations with Israel, Saudi Arabia, and other Arab countries in the region, we will see that none of the Eastern states can sacrifice these relations for the sake of relations with Iran.

Cooperation with all world powers and strategic regions, including the East with the important inclusion of Russia, India, and China is essential for any government, including the Islamic Republic of Iran, and no one should be blamed for concluding such agreements. If these agreements could create opportunities for helping the Iranian economy in the face of oppressive sanctions, they deserve credit. However, leaning on one or more powers and thinking that they could help us in confronting others is a recipe for problems, considering the facts that Iran's geostrategic position logically calls for a balanced and 
comprehensive policy. Furthermore, present-day realities and the basic principles of Eastern nations' policies do not offer a clear vision for Iran's Eastern policy as a fundamental strategy of long-term survival and development (Karami, 2020).

Considering the above, we can conclude that Iran's Eastern strategy faces challenges and limitations at all levels. Although this strategy is very important for Iran's economic and trade relations as well as for its technical and military needs, and can also prove effective in maintaining Iran's independence of action and contribute to stability and security of Iran's geopolitical environment, it will face problems in rolling back Western pressure in the long run or building an antiWestern coalition, and, therefore, Iran should not consider it a longterm and effective strategy.

The world will undergo fundamental changes in various dimensions in the next decade. One of such dimensions is the structure of the international system, which will become more multilateral and more multipolar, with more levels in political, security, and economic terms. Therefore, in formulating and regulating foreign policy strategies states have to consider new effective trends and new requirements arising from them, namely that the world will be more multi-polar, multi-level and multilateral. So, their governments should define national interests and formulate foreign policy accordingly.

Although the importance of the West is diminishing, its role cannot be denied altogether and the West will continue to play its important part. In contrast, the East will continue to rise, and its governments must consider their important and effective roles in shaping the future system and envisioning its rules, norms and structure. Eastern countries' concerns about changes in the Westphalian international system by the Western bloc and its exploitation of human rights and responsibility for humanitarian protection as excuses for trampling upon international law and interfering in other countries' internal affairs, as well as U.S. unilateralism in pressuring independent governments and imposing economic sanctions leave Eastern 
countries no choice but cooperate and take more responsibility in order to maintain their effective role in this process. The creation of institutions such as the SCO and the expansion of its membership and scope of functions and responsibilities, the EEU and its interactive mode, and the ECO and a possible expansion of its activities, the growing engagement between these three institutions and the rising inter-regionalism in Asia and Eurasia, and the broadening of this cooperation to Turkey are also important preconditions for an effective strategy to shape the future international system.

In this context, Iran's Eastern strategy will find a new meaning and concept. The importance, role and position of Iran in regional and international interactions is such that it creates effective possibilities for its role in the evolution of the international system. Iran's Eastern strategy is not merely a reaction to U.S. unilateralist policies, but an act of adapting to new global conditions. If this strategy is pursued in earnest, particularly in view of next year's presidential election and the Conservatives' higher chances of winning it, and if it becomes a serious priority in Iran's foreign policy, it could have important implications for Iran as well as for its relations with Russia and China.

Given its experience of effective cooperation with Russia in the field of counterterrorism and stabilization in other countries, its national and regional capacities as well as its important role in the ECO, its geopolitical position in the North-South corridor and the Asian Silk Road, Iran's position and role are key for the Eastern strategy. In other words, Iran will be the missing link in any regional and integrational initiative and order. Iran is the interface of cultural, intellectual, security and institutional trends in the three strategic regions of the Middle East, Eurasia, and Asia. These important communication features along with economic, energy and security capabilities can carve for Iran an important position as a responsible and positive actor in shaping the future regional and international system.

The experience of effective Iranian-Russian security cooperation in Syria will be an important possibility for stability and security in Afghanistan and Central Asia. Since U.S. forces have withdrawn from Afghanistan and ISIS and the Taliban are stepping up activities to assert 
their presence, security cooperation with Iran, especially within the framework of the SCO, can be of great importance and help avert or manage crises in this region. An unstable Afghanistan coupled with fragile governments in Central Asia will be the greatest vulnerability for any Asian order and any international system in the future.

At any rate, the success of Iran's Eastern strategy requires preventing the reinstatement of international sanctions, and this is one of the main weak points and a primary stumbling block of this strategy. Of course, as long as Iran remains in the JCPOA, it will not be possible for the sanctions to be formally reintroduced. As a result, the most important constraint of the Eastern strategy is that it will tie the possibility of Iran's participation in solving important international issues to the interaction among major world powers and work within the framework of international institutions. This highlights the necessity of adopting a more comprehensive strategy that can even include the Eastern strategy. From the authors' point of view, for all the importance and necessity of the Eastern strategy, the possibilities of Iran's foreign policy should not be limited solely to its framework. Iran should develop a grand strategy with emphasis on domestic needs and the priority of economic development at home, attaching importance to neighboring regions and a logical global balance, of which the Eastern strategy could be an important part.

\section{References}

Abyaneh, Ghadiri, 2021. Eghtesade Donya az Gharb be Shargh dar hale Obour Ast [The World Economy Is Moving from the West to the East]. Available at: https://www.irna.ir/news/84207838/ [Accessed 7 April 2021].

Adami, Ali, 2010. Negah be Shargh dar Syasate Khareji Iran: Didgah, Zamine ha va Forsat ha [Looking East in the Foreign Policy of the Islamic Republic of Iran: Opinions, Foundations and Opportunities]. Political Studies Quarterly, Spring, Vol. 2, No. 7; pp. 97-126.

Arghavani, Fariborz, 2015. Ravabete Iran va Chin dar Doureye Ahmadinejad, Negah be Shargh va Payamad haye Sakhtari: Fslname Motaleate Ravabete Beynolmelal [Iran-China Relations in the Age of Ahmadinejad: "Look East" 
Policy and Its Structural Implications]. International Relations Studies Quarterly, Winter 2016, 32(8), pp. 9-41.

Dirzauskaite, Goda and Nicolae Cristinel Ilinca, 2017. Understanding "Hegemony" in International Relations Theories. Available at: https://projekter. aau.dk/projekter/files/260247380.

Ehteshami, Anoushiravan and Gawdat Bahgat, 2019. Iran's Asianisation Strategy. In: Annalisa Perteghella (ed.) Iran Looking East. An Alternative to the EU? Milan: ISPI.

Esfandiary, Dina and Ariane, Tabatabai, 2018. Triple Axis: China, Russia, Iran and Power Politics. Available at: https://www.belfercenter.org/publication/tripleaxis-china-russia-iran-and-power-politics/

Esmaeili, Zainab, 2014. Taghdire Barzani az Yarye Iran Alayhe Daesh [Barzani's Thanks and Appreciation of Iran's Assistance Against ISIS]. Available at: https:// www.magiran.com/article/3013697/ [Accessed 7 April 2021].

Golmohamadi, Vali, 2018. The Foreign Policy of the Islamic Republic of Iran: Prospects for Change and Continuity. Available at: http://www.allazimuth. com/2018/12/22

Grachikov, Evgeny, 2020. China in Global Governance: Ideology, Theory, and Instrumentation. Russia in Global Affairs, 18(4) [online]. Available at: https:// eng.globalaffairs.ru/articles/china-in-global-governance/ [Accessed 1 September 2021].

Hadian, Naser, 2018. Mosahebe ba Asre Andishe [Interview with Asr-e Andisheh Magazine]. Asr-e Andisheh, 18.

Karami, Jahangir, 2015. L'Iran et l'Organisation de coopération de Shanghai. Capacités, obstacles et perspectives d'avenir. In : Chabal, P. (ed.) L'Organisation de coopération de Shanghai et la construction de la «nouvelle Asie». Zurich: Peter Lang International Academic Publication.

Karami, Jahangir, 2018. Iran's Eurasian Policy. Foreign Policy Quarterly, 32(4).

Karami, Jahangir, 2018. Mosahebe ba Asre Andishe [Interview with Magazine]. Asr-e Andisheh, 18.

Karami, Jahangir, 2020. Syasate Sharghye Irani [Iran's Eastern Policy]. Shargh Daily, 4698. Available at: https://www.etemadnewspaper.ir/fa/Main/ Detail/151411/ [Accessed 9 February 2021].

Keller, Siora, 2020. Understanding the Sino-Iranian Relationship under the Influence of US Sanctions [pdf]. Available at: https://projekter.aau.dk/projekter/ files/333575750/Master_s_Thesis_Siora_Keller.pdf 
Khamenei, Ali., 2016a. Speeches. Available at: https://farsi.khamenei.ir/32059

Khamenei, Ali, 2016b. Speeches. Available at: https://farsi.khamenei.ir/38981

Khamenei, Ali, 2018. Speeches. Available at: https://farsi.khamenei.ir/40714

Koulaee, Elahe, 2013. Naghde Syasate Negah be Sharg, Mosahebe ba Ruzname Shargh, [ Looking East Revisited. Interview with Shargh Daily]. Shargh Daily, No. 1812. Available at: https://www.magiran.com/article/2798577

Mahmoudian, Arman and Giorgio Cafiero, 2021. Does Russia Really Want a US Return to the Iran Deal? Available at: https:/www.atlanticcouncil.org/blogs/ iransource/does-russia-really-want-a-us-return-to-the-iran-deal

Morgan, Pippa and Kristensen, Peter Marcus, 2018. Leadership with Chinese Characteristics. Chinese Political Science Review, Vol. 3, pp. 1-9.

Mousavian, Seyed Hossein, 2020. Iran's New Doctrine: Pivot to the East. Available at: https://thediplomat.com/2020/10/irans-new-doctrine-pivot-to-the-east

Richardson, John, 2020. Iran and China New Deal Could Hasten Belt \& Road Initiative Petrochemicals Self-Sufficiency. Available at: https://www.icis.com/ asian-chemical-connections/2020/07

Saghafi Ameri, Naser and Ahadi, Afsaneh, 2008. Iran and Looking East Policy. Tehran: Center for Strategic Research.

Sajjadpour, Kazem, 2018. Mosahebe ba Asre Andishe [Interview with Asr-e Andisheh Magazine]. Asr-e Andisheh, 18.

Sanaei, Mehdi, 2017. Iran and Russia Relations. Available at: http://www.iras.ir/ en/doc/interview/3146.

Sanaei, Mehdi, 2019. Eastern Policy Will Be Reinforced in the World. Available at: https://www.salameno.com/news/20822679

Sanaei, Mehdi, 2020. Iran-Russia: Maintaining Bilateral Relations. Iran Review, 3/23.

Sanaei, Mehdi and Karami, Jahangir, 2019. International Multilateralism Current and Iran's Foreign Policy. Foreign Policy Quarterly, 33(2).

Sanaei, Mehdi and Karami, Jahangir, 2018. Iran and Economic Cooperation: From Atlantic to Pacific. Available at: http://www.iras.ir/en/doc/article/3783/iran-andeconomic-cooperation-from-atlantic-to-pacific

Sarma, Hriday, 2018. Turning the International North-South Corridor into a Digital Corridor. Brussels. 10.24411/2221-3279-2018-10008

Velayati, Ali Akbar, 2018. Iran's Velayati Clarifies Eastern Orientation Policy. Available at: https://www.tasnimnews.com/en/news/2018/09/17/1830679 